\title{
Prevalence of osteoarthritis of the knee in a random population sample of people aged $\mathbf{4 0}$ and older
}

\author{
David Rodriguez-Veiga, ${ }^{1}$ Cristina González-Martín, ${ }^{2}$ Sonia Pertega-Díaz, ${ }^{2}$ Teresa Seoane-Pillado, ${ }^{2}$ \\ María Barreiro-Quintás ${ }^{3}$ and Vanesa Balboa-Barreiro ${ }^{2}$ \\ ${ }^{1}$ Intensive Care Unit; ${ }^{2}$ Clinical Epidemiology Research Group, Instituto de Investigación Biomédica de A Coruña, Universidade da Coruña; ${ }^{3}$ nternal \\ Medicine Department, Complejo Hospitalario Universitario A Coruña. La Coruña, Spain
}

\begin{abstract}
Introduction: Osteoarthritis is the osteoarticular disease with the highest prevalence worldwide. In industrialized countries, $80 \%$ of the population > 65 years suffers from it. Objectives: To determine the prevalence of symptomatic osteoarthritis of the knee in a random population sample, its associated variables and its impact on pain and functionality. Methods: Descriptive and multivariate logistic regression analysis carried out at the Cambre Health Center, A Coruña. A sample of 707 patients was included. Anthropometric variables, comorbidity and clinical examination of the knees were assessed. The validated WOMAC and Lequesne questionnaires were used to assess pain and functionality. Results: $56.3 \%$ of the patients were females, and mean age was 61.75 years. The prevalence of symptomatic osteoarthritis in at least one knee was $29.3 \%$. People with osteoarthritis had higher scores in the pain, stiffness and functional capacity dimensions of the WOMAC questionnaire (30.0 $\pm 35.7,33.8 \pm$ 40.5 and $25.4 \pm 40.1$, respectively) and had higher scores in the Lequesne questionnaire as well (9.0 \pm 8.8$)$. Conclusions: $A$ high prevalence of people with osteoarthritis has been determined, which is modified with gender, age and body mass index.
\end{abstract}

KEY WORDS: Osteoarthritis. Knee. Pain. Stiffness.

\section{Introduction}

Traditionally, the concept of osteoarthritis has been focused on articular cartilage degradation. However, in recent years, the concept of the disease has changed, and it involves the rest of the anatomical structures that make up the joint: subchondral bone, ligaments, meniscus, joint capsule, synovial membrane and periarticular muscle, with the joint being regarded as a neuromusculoskeletal unit. ${ }^{1-4}$ Tissue injury mechanisms include mechanical and biological factors; in addition, osteoarthritis is a highly metabolically active disease..$^{5-7}$

Osteoarthritis is the osteoarticular disease with the highest prevalence in the entire world. In industrialized countries, $80 \%$ of the population older than 65 years suffer osteoarthritis ${ }^{8}$ and knee or hip involvement is the most common cause of ambulation disability in the elderly. ${ }^{9}$ In Spain, the symptomatic prevalence of osteoarthritis of the knee in people older than 20 years is $10.2 \%$ and that of symptomatic osteoarthritis of the hands is $6.2 \% .^{10}$

There are numerous epidemiological studies on the prevalence of osteoarthritis in different populations, but their results are not easy to be generalized and compared due to the variability in the definition of the disease (clinical or radiographic criteria), selection biases (participants' age and gender), selected joints, difficulty in establishing early symptoms of the disease and diversity in population pain threshold. .11-13 $^{-19}$

Osteoarthritis clinical data usually appear after 40 years of age, with gradual onset and slow evolution, with differences according to sites and individuals. Pain is the cardinal symptom (of mechanical characteristics). Other signs and symptoms include joint stiffness (of short duration), joint deformity, crepitus, weakness or instability. ${ }^{14-16}$
Correspondence:

Cristina González-Martín

E-mail: cristina.gmartin@udc.es
Date of reception: 31-07-2018

Date of acceptance: 10-09-2018

DOI: 10.24875/GMM.M19000231
Gac Med Mex. 2019;155:37-43

Contents available at PubMed www.gacetamedicademexico.com 
Tabla 1. General characteristics of the sample

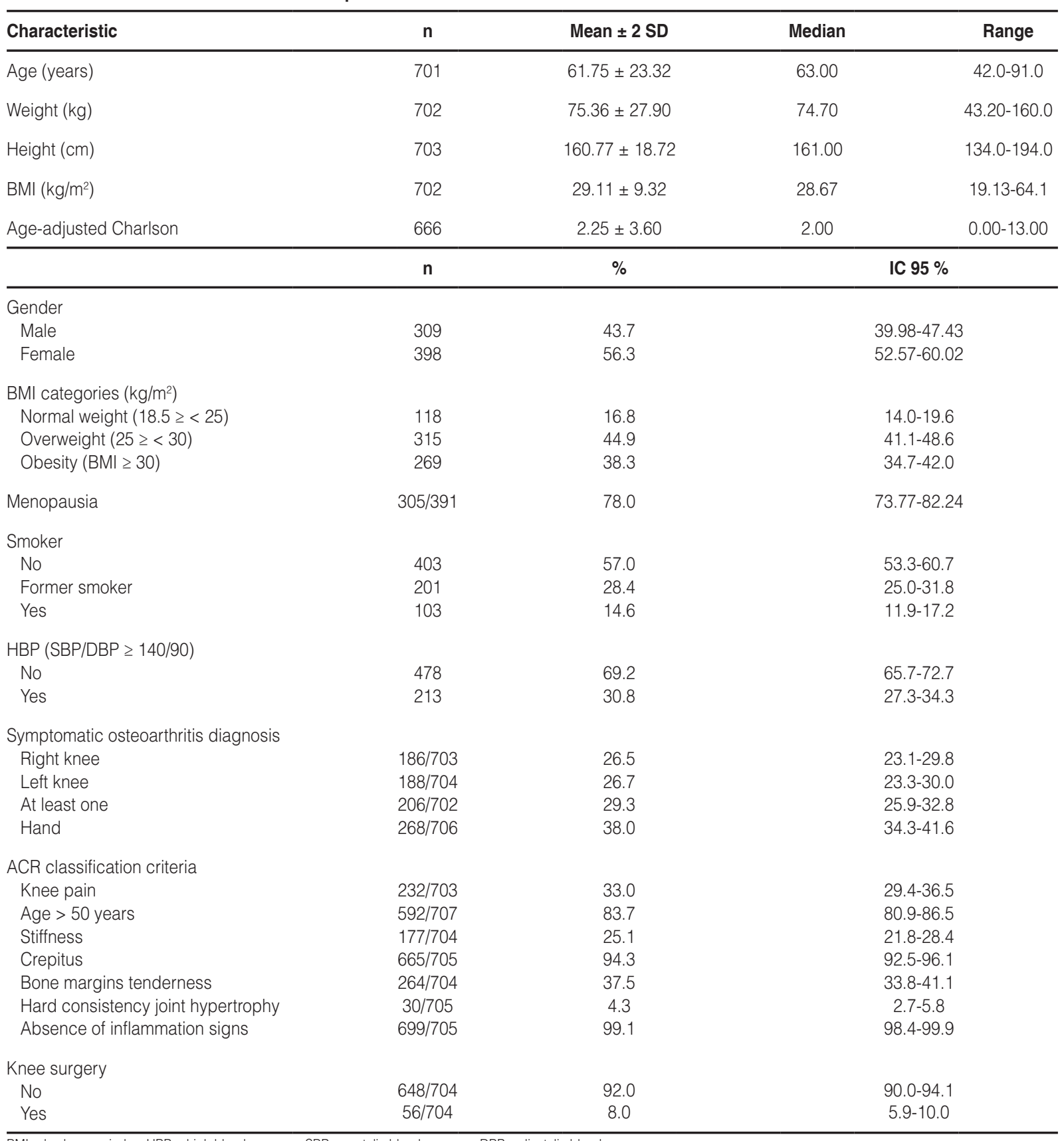

$\mathrm{BMI}=$ body mass index, $\mathrm{HBP}=$ high blood pressure, $\mathrm{SBP}=$ systolic blood pressure, $\mathrm{DBP}=$ diastolic blood pressure.

Taking into account the magnitude and impact of the disease, this research had the purpose to determine the prevalence of symptomatic osteoarthritis of the knee in a random population sample aged 40 and older, as well as the variables associated with its occurrence.

\section{Method}

Observational study on the prevalence of osteoarthritis in the municipality of Cambre, A Coruña, Galicia, Spain. Cambre inhabitants of 40 years of age or older who granted their consent to participate in the study were included.

In this study, a sample size of 707 patients (309 men and 398 women) was obtained, which allowed to determine the prevalence of osteoarthritis of the knee in people aged 40 or older, taking into account the population of the Cambre municipality according to data of the National Institute of Statistics of Spain and after conducting a stratified random sampling by age groups (40 to 64 years and older than 65) and gender, through data of the health card, with a $95 \%$ confidence level 
$(\alpha=0.05)$, an accuracy of $\pm 4 \%$ and assuming an attrition percentage of $11 \%$.

Authorization of the Clinical Research Ethics Committee of Galicia was requested. Possible participants were contacted by postal mail, explaining the characteristics of the study. Subsequently, those who were interested received a telephone call to make an appointment at the Cambre Health Center. After having accepted to participate, in the visit to the health center, the patient was examined and information was collected.

\section{Measurements and interventions}

Sociodemographic (age, gender) and anthropometric variables (weight, height, body mass index $[\mathrm{BMI}]$ ) were assessed, as well as high blood pressure (HBP), tobacco consumption, comorbidities (Charlson score), disease variables (American College of Rheumatology classification criteria and surgical history) and the WOMAC ${ }^{17}$ and Lequesne ${ }^{18}$ questionnaires for patient pain assessment and functional assessment. The former consists of 24 items that evaluate three dimensions (pain, stiffness and functionality) and the latter has 11, which assess pain, discomfort and functionality. Examination of the knee joints was carried out taking into account the American College of Rheumatology clinical criteria. ${ }^{19,20}$

A descriptive analysis of the variables included in the study was carried out. Quantitative variables were expressed as the mean $\pm 2 \mathrm{SD}$, median and range; qualitative variables were expressed as frequencies and percentages, indicating their corresponding $95 \%$ confidence interval. The association between qualitative variables was analyzed by means of chi-square or Fisher tests. The comparison of means was performed using Student's t-test or Mann-Whitney's U-test. Consistency between the questionnaires used for pain and functionality assessment was analyzed using Spearman's correlation coefficient. The variables associated with osteoarthritis of the knee were determined through logistic regression models.

\section{Results}

There was a slight predominance of women, with a mean age of $61.75 \pm 23.32$ years. There was a high prevalence of overweight $(44.9 \%)$ and obesity $(38.3 \%)$ recorded. The study sample showed a prevalence of smoking of $14.6 \%$ and high blood pressure of $30.8 \%$. Age-adjusted median Charlson score was 2.0 (Table 1).
Table 2. Variables associated with the presence of osteoarthritis in at least one knee

\begin{tabular}{|c|c|c|c|c|c|}
\hline \multirow[t]{3}{*}{ Variable } & \multicolumn{4}{|c|}{$\begin{array}{l}\text { Osteoarthritis in at least } \\
\text { one knee }\end{array}$} & \multirow[t]{3}{*}{$p$} \\
\hline & \multicolumn{2}{|c|}{ No } & \multicolumn{2}{|c|}{ Yes } & \\
\hline & \multicolumn{2}{|c|}{ Mean \pm 2 SD } & \multicolumn{2}{|c|}{ Mean \pm 2 SD } & \\
\hline Age & \multicolumn{2}{|c|}{$60.3 \pm 23.6$} & \multicolumn{2}{|c|}{$64.9 \pm 21.0$} & $<0.001$ \\
\hline Menopause age & \multicolumn{2}{|c|}{$49.3 \pm 10.4$} & \multicolumn{2}{|c|}{$49.3 \pm 10.8$} & 0.979 \\
\hline BMl & \multicolumn{2}{|c|}{$28.4 \pm 8.8$} & \multicolumn{2}{|c|}{$30.8 \pm 9.8$} & $<0.001$ \\
\hline \multirow[t]{2}{*}{ Charson score } & \multicolumn{2}{|c|}{$2.0 \pm 3.4$} & \multicolumn{2}{|c|}{$2.8 \pm 3.8$} & $<0.001$ \\
\hline & $\mathbf{n}$ & $\%$ & n & $\%$ & \\
\hline \multicolumn{6}{|l|}{ Age group } \\
\hline $40-64$ years & 287 & 75.9 & 91 & 24.1 & $<0.001$ \\
\hline$\geq 65$ years & 204 & 41.5 & 114 & 55.6 & \\
\hline \multicolumn{6}{|l|}{ Gender } \\
\hline Male & 248 & 81.0 & 58 & 19.0 & $<0.001$ \\
\hline Female & 248 & 62.6 & 148 & 37.4 & \\
\hline \multicolumn{6}{|l|}{ Smoker } \\
\hline No & 255 & 63.7 & 145 & 36.3 & $<0.001$ \\
\hline Yes & 241 & 79.8 & 61 & 20.2 & \\
\hline \multicolumn{6}{|l|}{ BMl categories $\left(\mathrm{kg} / \mathrm{m}^{2}\right)$} \\
\hline Normal weight $(18.5 \geq<25)$ & 104 & 88.1 & 14 & 11.9 & $<0.001$ \\
\hline Overweight $(25 \geq<30)$ & 229 & 73.6 & 82 & 26.4 & \\
\hline Obesity (BMI $\geq 30$ ) & 159 & 59.3 & 109 & 40.7 & \\
\hline \multicolumn{6}{|l|}{ Osteoarthritis of the hands } \\
\hline No & 353 & 81.0 & 83 & 19.0 & $<0.001$ \\
\hline Yes & 143 & 54.0 & 122 & 46.0 & \\
\hline \multicolumn{6}{|l|}{ HBP } \\
\hline No & 328 & 73.5 & 118 & 26.5 & 0.023 \\
\hline Yes & 156 & 65.3 & 83 & 34.7 & \\
\hline
\end{tabular}

According to the American College of Rheumatology diagnostic criteria, osteoarthritis symptomatic prevalence in at least one knee in the general sample was determined to be $29.3 \%$; the appearance of osteoarthritis in the hands (38.0\%) was more frequent. The most common signs and symptoms were inflammation absence, crepitus and pain (Table 1).

In the bivariate analysis, symptomatic osteoarthritis of the knee was significantly associated with the following variables (Table 2): age, gender, tobacco exposure, BMI, symptomatic osteoarthritis of the hand diagnosis and Charlson score. A history of high blood pressure was significantly associated with osteoarthritis of at least one knee.

Patients with osteoarthritis of the knee were older ( $64.9 \pm 21.0$ vs. $60.3 \pm 23.6$ years); osteoarthritis was more common in patients aged 65 or older. This pathology occurred more frequently in women $(37.4 \%$ vs. 
Table 3. Association of pain, general status, age and symptoms with the presence of osteoarthritis in at least one knee

\begin{tabular}{|c|c|c|c|c|c|}
\hline \multirow[t]{3}{*}{ Variable } & \multicolumn{4}{|c|}{ Osteoarthritis in at least one knee } & \multirow[t]{3}{*}{ p } \\
\hline & \multicolumn{2}{|c|}{ No } & \multicolumn{2}{|c|}{ Yes } & \\
\hline & \multicolumn{2}{|c|}{ Mean \pm SD } & \multicolumn{2}{|c|}{ Mean \pm SD } & \\
\hline Pain in the preceding week & \multicolumn{2}{|c|}{$2.66 \pm 6.20$} & \multicolumn{2}{|c|}{$6.10 \pm 5.30$} & $<0.001$ \\
\hline Patient general status assessment & \multicolumn{2}{|c|}{$2.45 \pm 3.44$} & \multicolumn{2}{|c|}{$4.78 \pm 4.20$} & $<0.001$ \\
\hline \multirow[t]{2}{*}{ Observer assessment } & \multicolumn{2}{|c|}{$2.03 \pm 3.24$} & \multicolumn{2}{|c|}{$5.11 \pm 4.00$} & $<0.001$ \\
\hline & $\mathrm{n}$ & $\%$ & $\mathrm{n}$ & $\%$ & \\
\hline \multicolumn{6}{|l|}{ Pain right knee } \\
\hline $\begin{array}{l}\text { No } \\
\text { Yes }\end{array}$ & $\begin{array}{c}470 \\
26\end{array}$ & $\begin{array}{c}94.8 \\
5.2\end{array}$ & $\begin{array}{c}1 \\
205\end{array}$ & $\begin{array}{c}0.5 \\
99.5\end{array}$ & $<0.001$ \\
\hline \multicolumn{6}{|l|}{ Age $>50$ years } \\
\hline $\begin{array}{l}\text { No } \\
\text { Yes }\end{array}$ & $\begin{array}{l}105 \\
411\end{array}$ & $\begin{array}{l}20.3 \\
79.7\end{array}$ & $\begin{array}{c}10 \\
178\end{array}$ & $\begin{array}{r}5.3 \\
94.7\end{array}$ & $<0.001$ \\
\hline \multicolumn{6}{|l|}{ Right knee stiffness } \\
\hline $\begin{array}{l}\text { No } \\
\text { Yes }\end{array}$ & $\begin{array}{c}479 \\
16\end{array}$ & $\begin{array}{c}96.8 \\
3.2\end{array}$ & $\begin{array}{c}48 \\
158\end{array}$ & $\begin{array}{l}23.3 \\
76.7\end{array}$ & $<0.001$ \\
\hline \multicolumn{6}{|l|}{ Knee crepitus } \\
\hline $\begin{array}{l}\text { No } \\
\text { Yes }\end{array}$ & $\begin{array}{c}39 \\
457\end{array}$ & $\begin{array}{r}7.9 \\
92.1\end{array}$ & $\begin{array}{c}1 \\
205\end{array}$ & $\begin{array}{r}0.5 \\
99.5\end{array}$ & $<0.001$ \\
\hline \multicolumn{6}{|l|}{ Tenderness } \\
\hline $\begin{array}{l}\text { No } \\
\text { Yes }\end{array}$ & $\begin{array}{c}422 \\
73\end{array}$ & $\begin{array}{l}85.3 \\
14.7\end{array}$ & $\begin{array}{c}17 \\
189\end{array}$ & $\begin{array}{r}8.3 \\
91.7\end{array}$ & $<0.001$ \\
\hline \multicolumn{6}{|l|}{ Knee hypertrophy } \\
\hline $\begin{array}{l}\text { No } \\
\text { Yes }\end{array}$ & $\begin{array}{c}496 \\
0\end{array}$ & $\begin{array}{c}100 \\
0\end{array}$ & $\begin{array}{l}177 \\
29\end{array}$ & $\begin{array}{l}85.9 \\
14.1\end{array}$ & $<0.001$ \\
\hline \multicolumn{6}{|l|}{ Knee inflammation } \\
\hline $\begin{array}{l}\text { No } \\
\text { Yes }\end{array}$ & $\begin{array}{c}490 \\
6\end{array}$ & $\begin{array}{c}98.8 \\
1.2\end{array}$ & $\begin{array}{c}206 \\
0\end{array}$ & $\begin{array}{c}100 \\
0\end{array}$ & $<0.001$ \\
\hline
\end{tabular}

$19.0 \%)$, in patients with symptomatic osteoarthritis of the hand $(46.0 \%$ vs. $19.0 \%)$, with higher BMI and in non-smokers. In turn, a higher prevalence of osteoarthritis was observed in hypertensive patients $(34.7 \%$ vs. $26.5 \%)$ and higher comorbidity values according to the Charlson score (2.8 \pm 3.8 vs. $2.0 \pm 3.4)$ (Table 2).

Of the patients without a diagnosis of symptomatic osteoarthritis, $5.2 \%$ referred pain and $3.2 \%$ stiffness in at least one knee, in comparison with $99.5 \%$ and $76.7 \%$ of patients with symptomatic osteoarthritis (Table 3).

Considering all variables, and adjusting a multivariate logistic regression model, the variables that were identified to have an independent effect associated with symptomatic osteoarthritis in at least one knee were age, gender and BMI classification. Women were at higher risk to develop symptomatic osteoarthritis of the knee (odds ratio $[\mathrm{OR}]=2.85$ ); the older the age, the higher the risk $(\mathrm{OR}=1.03)$; and patients with
Table 4. Logistic regression model to determine the variables with an impact on the probability of symptomatic osteoarthritis of the knee

\begin{tabular}{lccccc}
\hline Variable & B & EoT & $\mathbf{p}$ & OR & 95\% Cl \\
\hline Gender (female) & 1.047 & 0.187 & $<0.001$ & 2.849 & $1.974-4.112$ \\
Age & 0.031 & 0.008 & $<0.001$ & 1.031 & $1.015-1.047$ \\
BMl $25-30 \mathrm{~kg} / \mathrm{m}^{2}$ & 1.079 & 0.321 & $<0.001$ & 2.942 & $1.570-5.514$ \\
BMl $>30 \mathrm{~kg} / \mathrm{m}^{2}$ & 1.582 & 0.320 & $<0.001$ & 4.866 & $2.600-9.108$ \\
Constant & -4.577 & 0.588 & $<0.001$ & 0.010 & \\
\hline
\end{tabular}

$\mathrm{BMI}=$ body mass index, $\mathrm{Cl}=$ confidence interval

overweight $(\mathrm{OR}=2.94)$ or obesity $(\mathrm{OR}=4.87)$ had a higher risk than those with normal weight (Table 4).

Mean global score for the Lequesne knee questionnaire was $4.01 \pm 4.59$ (Table 5), and it was higher in patients with symptomatic osteoarthritis of the knee (8.97 \pm 8.86 vs. $1.92 \pm 5.28)$.

The dimension with the highest score was that of pain. According to the degree of severity as determined 
Table 5. Lequesne and WOMAC index in at least one knee and both questionnaires

\begin{tabular}{|c|c|c|c|c|}
\hline \multirow[t]{3}{*}{ Indicator } & \multicolumn{3}{|c|}{ Osteoarthritis in at least one knee } & \multirow[t]{3}{*}{$\mathrm{p}$} \\
\hline & Overall & No & Yes & \\
\hline & Mean \pm SD & Mean \pm SD & Mean \pm SD & \\
\hline \multicolumn{5}{|l|}{ Lequesne dimensions } \\
\hline Pain & $1.91 \pm 4.82$ & $0.79 \pm 3.00$ & $4.57 \pm 4.08$ & $<0.001$ \\
\hline Maximum distance walked & $0.88 \pm 2.22$ & $0.60 \pm 1.54$ & $1.56 \pm 2.92$ & $<0.001$ \\
\hline ADL & $1.22 \pm 3.46$ & $0.53 \pm 2.02$ & $2.84 \pm 3.92$ & $<0.001$ \\
\hline Total score & $4.01 \pm 9.18$ & $1.92 \pm 5.28$ & $8.97 \pm 8.86$ & $<0.001$ \\
\hline \multicolumn{5}{|l|}{ WOMAC dimensions } \\
\hline Pain & $12.39 \pm 35.20$ & $4.98 \pm 21.86$ & $30.05 \pm 35.70$ & $<0.001$ \\
\hline Stiffness & $13.65 \pm 39.98$ & $4.97 \pm 23.72$ & $33.86 \pm 40.52$ & $<0.001$ \\
\hline \multirow[t]{2}{*}{ Functional capacity } & $10.74 \pm 32.82$ & $4.51 \pm 18.16$ & $25.41 \pm 40.14$ & $<0.001$ \\
\hline & $\mathrm{n}$ & $\%$ & $95 \% \mathrm{Cl}$ & \\
\hline \multicolumn{5}{|l|}{ Lequesne severity } \\
\hline None & 184 & 26.1 & $22.7-29.4$ & \\
\hline Mild & 265 & 37.5 & $33.9-41.2$ & \\
\hline Moderate & 76 & 10.8 & $8.4-13.1$ & \\
\hline Severe & 87 & 12.3 & $9.8-14.8$ & \\
\hline Very severe & 69 & 9.8 & $7.5-12.0$ & \\
\hline Extremely severe & 25 & 3.5 & $2.1-4.9$ & \\
\hline
\end{tabular}

by the questionnaire, $37.5 \%$ showed slight alteration and $26.1 \%$ were unaffected. In patients with symptomatic osteoarthritis of the knee, the WOMAC questionnaire standardized score was significantly higher in all its dimensions (pain, rigidity and functional capacity). A high, positive and significant correlation $(p<0.001)$ was observed between the Lequesne knee questionnaire and different dimensions of the WOMAC questionnaire, with the correlation with functional capacity standing out $(r=0.888)$ (Table 6).

\section{Discussion}

Regarding the general characteristics of the studied patients, there was a discrete predominance of women in relation to men, as it corresponds to the gender distribution in the population (56.3\% vs. $43.7 \%$ ). Mean age of the studied sample was $61.75 \pm$ 23.32 years.

There was a high prevalence of overweight ( $44.9 \%)$ and obesity $(38.3 \%)$. These results are consistent with those of other national and international epidemiological studies, taking into account the age group (people aged 40 and older). ${ }^{21-24}$ According to the Charlson score, the most prevalent pathology was diabetes mellitus, with $10.7 \%$. Similar values have been found in other investigations..$^{25-27}$ In this study, the American College of Rheumatology clinical criteria were used for the diagnosis of osteoarthritis, with the
Table 6. Correlation between Lequesne score and WOMAC questionnaire different domains

\begin{tabular}{ccccc}
\hline & \multicolumn{3}{c}{ WOMAC } \\
\cline { 2 - 4 } & Pain & Stiffness & Functional capacity \\
\hline Lequesne & $\begin{array}{l}\text { Correlation } \\
\text { coefficient }\end{array}$ & 0.821 & 0.645 & 0.888 \\
$p$ & $<0.001$ & $<0.001$ & $<0.001$ \\
\hline
\end{tabular}

performance of X-rays being avoided in order to minimize the risk of radiation for the patients. A high prevalence of symptomatic osteoarthritis knee was determined $(29.3 \%)$, which was within the range observed in the literature.

In the Pereira systematic review, ${ }^{28}$ as well as in the study carried out in Korea by Inje Kim et al. ${ }^{29}$ and in the one by Lethbridge et al. $^{30}$, a prevalence of osteoarthritis of the knee between 18.9 and 37.3 $\%$ was estimated (by clinical and radiographic criteria), which are data consistent with the findings of our analysis. The review by Pereira ${ }^{28}$ confirms the existence of high heterogeneity between different works. In line with the results of other investigations, ${ }^{30-32}$ the prevalence of osteoarthritis of the knee was considerably higher in the female gender. We were able to determine that the variables that were independently associated with symptomatic osteoarthritis of the knee were age, gender (being a woman) and BMI. 
The high prevalence of symptomatic osteoarthritis of the knee in our study can be explained by the inclusion of people with a high mean age and by the larger proportion of women than of men. These results are consistent with those reported in the reviewed literature, ${ }^{29,31-35}$ where a higher prevalence of osteoarthritis is observed in older patients and in the female gender.

In this study, validated questionnaires were used to assess pain and functional capacity in osteoarthritis (Lequesne index and WOMAC questionnaire), by means of which a high correlation between Lequesne total score and WOMAC different dimensions (pain, stiffness and functional capacity) were obtained

Numerous works highlight the involvement of the WOMAC questionnaire dimensions in patients with osteoarthritis of the knee and hip. ${ }^{36-38}$ The results derived from our study showed that patients with symptomatic osteoarthritis of the knee had a significantly higher scores in all WOMAC dimensions, which implies greater pain, stiffness and functional limitation, which were results that were expected. Similarly, other analyse ${ }^{39,40}$ have obtained worse results in the pain, stiffness and functional capacity dimensions in comparison with patients without osteoarthritis, just as it was found in our work.

Among the limitations of this research, we can mention that, to minimize the selection bias, a randomized study of the general population was carried out, where younger than 40 years' or immobilized patients were excluded. Information bias was minimized by using validated questionnaires and previously trained personnel to carry out the clinical examination. To minimize the confounding bias, variables were collected that might modify objective quality of life, pain, stiffness and functional capacity measurement parameters, such as patient comorbidity. In turn, the confounding effect was controlled using multivariate regression techniques.

\section{Conclusions}

We determined a high prevalence of people with osteoarthritis, which is modified by gender, age and BMI.

Patients with osteoarthritis had higher scores in the Lequesne questionnaire, in comparison with those without it. The most common degree of compromise was mild compromise.

WOMAC questionnaire scores in patients with osteoarthritis were clearly higher than in patients without osteoarthritis.

\section{Acknowledgements}

This work was partially subsidized by concession Si427C 2011/56-0 of the Xunta de Galicia, Xeral de Ios Igualdades Secretariat, and the European Social Fund. Also, our thanks to Salvador Pita Fernández, for the conception, design and implementation of the study.

\section{References}

1. Mas-Garriga X. Definición, etiopatogenia, clasificación y formas de presentación. Aten Primaria. 2014;46:3-10.

2. Hurley MV. El papel de la debilidad muscular en la patogenia de la artrosis. Rheu Dis Clin Am. 1999;1:283-299.

3. Brandt KD, Radin EL, Dieppe PA, Van de Putte L. Yet more evidence that osteoarthritis is not a cartilage disease. Ann Rheum Dis. 2006;65: 1261-1264.

4. Sociedad Española de Reumatología. Artrosis. Fisiopatología, diagnóstico y tratamiento. España: Médica Panamericana; 2010.

5. Arliani GG, Astur DC, Yamada RK, Yamada AF, Miyashita GK, Mandelbaum $B$, et al. Early osteoarthritis and reduced quality of life after retirement in former professional soccer players. Clinics (Sao Paull). 2014; 69:589-594

6. Mayan MD, Gago-Fuentes R, Carpintero-Fernández P, Fernández-Puente $\mathrm{P}$, Filgueira-Fernández $\mathrm{P}$, Goyanes $\mathrm{N}$, et al. Articular chondrocyte network mediated by gap junctions: role in metabolic cartilage homeostasis. Ann Rheum Dis. 2015;74:275-284.

7. Mayan MD, Carpintero-Fernández P, Gago-Fuentes R, Martínez-De-llarduya O, Hong-Zhang W, Valiunas V, et al. Human articular chondrocytes express multiple gap junction proteins: differential expression of connexins in normal and osteoarthritic cartilage. Am J Pathol. 2013;182:1337-1346.

8. Woolf AD, Pfleger B. Burden of major musculoskeletal conditions. Bull World Health Organ. 2003;81:646-656.

9. Bernad-Pineda M, De las Heras-Sotos J, Garcés-Puentes MV. Calidad de vida en pacientes con artrosis de rodilla y/o cadera. Rev Esp Cir Ortop Traumatol. 2014;58:283-289.

10. Carmona L, Ballina J, Gabriel R, Laffon A. The burden of musculoskeletal diseases in the general population of Spain: results from a national survey. Ann Rheum Dis. 2001;60:1040-1045.

11. Busija L, Bridgett L, Williams SR, Osborne RH, Buchbinder R, March L, et al. Osteoarthritis. Best Pract Res Clin Rheumatol. 2010;24:757-768.

12. Poley-González A, Ortega-Blanco JA, Pedregal-González M, Martín-Azofra M, Hermosilla-Camacho C, Mora-Moreno F. Prevalencia de enfermedades osteoarticulares y consumo de recursos. Calidad de vida y dependencia en pacientes con artrosis. Semergen. 2011;37:462-467.

13. Zhang Y, Jordan JM. Epidemiology of osteoarthritis. Clin Geriatr Med. 2010;26:355-369.

14. Pérez-Martín A. Clínica. Localizaciones: rodilla, cadera, manos, columna, otras localizaciones. Aten Primaria. 2014:46:11-17.

15. Castaño-Carou A. Evaluación clínica del paciente con artrosis. Estudio multicéntrico nacional "EVALÚA". España: Servicio de Publicaciones Universidade da A Coruña; 2014.

16. Sinusas K. Osteoarthritis: diagnosis and treatment. Am Fam Physician. 2012;85:49-56.

17. Bellamy N, Buchanan WW, Goldsmith $\mathrm{CH}$, Campbell J, Stitt LW. Validation study of WOMAC: a health status instrument for measuring clinically important patient relevant outcomes to antirheumatic drug therapy in patients with osteoarthritis of the hip or knee. J Rheumatol. 1988;15:1833-1840.

18. Lequesne MG. The algofunctional indices for hip and knee osteoarthritis. J Rheumatol. 1997;24:779-781.

19. Altman R, Asch E, Bloch D, Bole G, Borenstein D, Brandt K, et al. Development of criteria for the classification and reporting of osteoarthritis. Classification of osteoarthritis of the knee. Diagnostic and Therapeutic Criteria Committee of the American Rheumatism Association. Arthritis Rheum. 1986;29:1039-1049.

20. Altman R, Alarcón G, Appelrouth D, Bloch D, Bole G, Borenstein D, et al. The American College of Rheumatology criteria for the classification and reporting of osteoarthritis of the hand. Arthritis Rheum. 1990;33:1601-1610.

21. Berghöfer A, Pischon T, Reinhold T, Apovian CM, Sharma AM, Willich SN. Obesity prevalence from European perspective: a systematic review. BMC Public Health. 2008;8:200.

22. Aranceta-Bartrina J, Pérez-Rodrigo C, Alberdi-Aresti G, Ramos-Carrera N, Lázaro-Masedo S. Prevalencia de obesidad general y obesidad abdominal en la población adulta española (25-64 años) 2014-2015: estudio ENPE. Rev Esp Cardiol. 2016;69:579-587. 
23. Gutiérrez-Fisac JL, Guallar-Castillón P, León-Muñoz LM, Graciani A, Banegas JR, Rodríguez-Artalejo F. Prevalence of general and abdomina obesity in the adult population of Spain, 2008-2010: the ENRICA study. Obes Rev. 2012;13:388-392.

24. Ogden CL, Carroll MD, Kit BK, Flegal KM. Prevalence of childhood and adult obesity in the United States, 2011-2012. JAMA. 2014;311:806-814.

25. DECODE Study-Group. Age- and sex-specific prevalences of diabetes and impaired glucose regulation in 13 European cohorts. Diabetes Care. 2003;26:61-69.

26. Valdés S, Rojo-Martínez G, Soriguer F. Evolution of prevalence of type 2 diabetes in adult Spanish population. Med Clin (Barc). 2007:129:352-355

27. Soriguer F, Goday A, Bosch-Comas A, Bordiú E, Calle-Pascual A, Carmena $R$, et al. Prevalence of diabetes mellitus and impaired glucose regulation in Spain: the Di@bet.es Study. Diabetologia. 2012;55:88-93.

28. Pereira D, Peleteiro B, Araúio J, Branco J, Santos RA, Ramos E. The effect of osteoarthritis definition on prevalence and incidence estimates: a systematic review. Osteoarthritis Cartillage. 2011;19:1270-1285.

29. Kim I, Kim AH, Seo YI, Song YW, Jeong JY, Kim DY. The prevalence of knee osteoarthritis in elderly community residents in Korea. J Korean Med Sci. 2010;25:293-298.

30. Lethbridge-Cejku M, Tobin JD, Scott WW, Reichle R, Plato CC, Hochberg MC. The relationship of age and gender to prevalence and pattern of radiographic changes of osteoarthritis of the knee: data from caucasian participants in the Baltimore Longitudinal Study of Aging. Aging (Milano). 1994;6:353-357.

31. Dahaghin S, Bierma-Zeinstra SM, Ginai AZ, Pols HA, Hazes JM Koes W. Prevalence and pattern of radiographic hand osteoarthritis and association with pain and disability (the Rotterdam study). Ann Rheum Dis. 2005; 64:682-687.

32. Zhang Y, Niu J, Kelly-Hayes M, Chaisson CE, Aliabadi P, Felson DT. Prevalence of symptomatic hand osteoarthritis and its impact on func- tional status among the elderly: the Framingham Study. Am J Epidemiol. 2002;156:1021-1027.

33. Peat G, McCarney R, Croft P. Knee pain and osteoarthritis in older adults: a review of comunity burden and current use of primary health care. Ann Rheum Dis. 2001;60:91-97.

34. Liu Y, Zhang H, Liang N, Fan W, Li J, Huang Z, et al. Prevalence and associated factors of knee osteoarthritis in a rural Chinese adult population: an epidemiological survey. BMC Public Health. 2016;16:94.

35. Silverwood V, Blagojevic-Bucknall M, Jinks C, Jordan JL, Protheroe J, Jordan KP. Current evidence on risk factors for knee osteoarthritis in older adults: a systematic review and meta-analysis. Osteoarthritis Cartilage. 2015;23:507-515.

36. Basaran S, Guzel R, Seydaoglu G, Guler-Uysal F. Validity, reliability, and comparison of the WOMAC osteoarthritis index and Lequesne algofunctional index in Turkish patients with hip or knee osteoarthritis. Clin Rheumatol. 2010;29:749-756.

37. Reolid-Martínez R, Matos-Berroa S, Ayuso-Raya MC, De los SantosBerrido E, Castro-Hurtado S, Arias-Alaminos M, et al. Capacidad funcional, características del dolor y tratamiento farmacológico en pacientes con artrosis de rodilla. Rehabilitacion. 2014;48:226-231.

38. Debi R, Mor A, Segal O, Segal G, Debbi E, Agar G, et al. Differences in gait patterns, pain, function and quality of life between males and females with knee osteoarthritis: a clinical trial. BMC Musculoskelet Disord. 2009;10:127.

39. Kim I, Kim HA, Seo YI, Song YW, Hunter DJ, Jeong JY, et al. Tibiofemoral osteoarthritis affects quality of life and function in elderly Koreans, with women more adversely affected than men. BMC Musculoskelet Disord. 2010;11:129.

40. Kim IJ, Kim HA, Seo YI, Jung YO, Song YW, Jeong JY, et al. Prevalence of knee pain and its influence on quality of life and physical function in the Korean elderly population: a community based cross-sectional study. J Korean Med Sci. 2011;26:1140-1146. 